\title{
Childhood Extragonadal Malignant Germ Cell Tumor
}

National Cancer Institute

\section{Source}

National Cancer Institute. Childhood Extragonadal Malignant Germ Cell Tumor. NCI

Thesaurus. Code C68632.

A malignant germ cell tumor in children arising from an anatomic site other than the testis or ovary. 